\section{WAR SURGERY}

Dear Editor,

D eference is made to article "War Wounds Changing Concepts" Rublished in MJAFI 2002;58:192-5. I would like to highlight the following points.

1. Authors have not clearly stated that figure 1489 pertains to number of casualties (as mentioned in material \& methods) or number of wounds as per sum total of injuries at table 1 and as per abstracts.

2. In results authors have stated that GSW accounted for $55.54 \%$ $(\mathrm{N}=827)$ of casualties and $44.46 \%(\mathrm{~N}=662)$ had suffered blast injuries. That makes total number of casualties as 1489 $(827+662)$.

Authors further state " $23 \%$ of patients $(\mathrm{N}=340)$ had more than two sites involved". Let us presume that 340 patients mentioned above had 3 wounds each at different sites then the total number of wounds sustained would be 1020 (340 x 3). As per table 1 total number of wounds sustained were 1489 .

Therefore rest of patients 1149 (1489 - 340) sustained 469 wounds (1489-1020) a clearly absurd situation implying that 1149 patients sustained less than half wound each.

Let us presume that 1149 patients sustained at least one wound each, then total number of wounds would be $2169,(1149+1020)$. 2169 should be the minimal number of wound sustained by 1489 patients, if one logically analyses the said article.

3. In results it is stated that table 2 shows percentage of bone and soft tissue injuries whereas it is not shown in table 2 .

4. Further, in results it is stated that $63 \%$ of injuries involved extremities while as per table 3 it is $70.59 \%$.

5. Sum total of soft tissue injuries involving limbs is 535 (as per table 2) where as it is 557 as per table 3 .

6. Table 3 depicts chest wounds $(\mathrm{N}=39)$, abdominal wall injuries $(\mathrm{N}=17)$ \& trunk injuries $(\mathrm{N}=29)$. Isn't chest and abdominal wall part of trunk? Why have they been depicted separately?

7. In material and methods, authors have stated that time lag

Reply

At the outset we thank the reader for his learned observations and accept a few printing mistakes, as the article shuttled for security clearance in various directions for over 2 years. The figure of 1489 pertains to the number of casualties and not the wounds. The percentage values in Table 2 are missing as rightly pointed out. 789 patients had isolated soft tissue injuries and the article discusses the effect of primary closure and infection rate in this group to the exclusion of the 700 patients with other injuries. Table 2 refers to the whole group of 1489 patients while Table 3 deals with 789 who had soft tissue injuries alone, therefore the variation in percentage of extremity injury in the two tables. The chest injuries and abdominal injuries have been separated from the since injury was routinely $>6 \mathrm{hrs}$ whereas in discussion they state that wound closed within $6 \mathrm{hrs}$ had infection rate of $4.87 \%$ and those closed after $6 \mathrm{hrs}$ had infection rate of $6.36 \%$. As per table 4 , these figures correspond to primary closure as 369 and delayed primary closure 220 cases. If they were able to close $47 \%$ wounds $(\mathrm{N}=369)$ within 6 hrs how then can time lag be routinely $>6 \mathrm{hrs}$.

8. Continuing the same point that infection rate for wound closed within 6 hrs was $4.87 \%$ (total wound 369 ) and $6.36 \%$ if closed after $6 \mathrm{hrs}(\mathrm{N}=220)$ where as in material and methods they have stated that criteria for selection of a wound for a primary closure or delayed primary closure was solely clinical contamination and not time lag since injury which was routinely $>6 \mathrm{hrs}$ where as it is clear that all wounds irrespective of their contaminated state were subjected to primary closure if they reported within $6 \mathrm{hrs} \&$ DPS if reported after $6 \mathrm{hrs}$.

9. In discussion they have stated conversion rate was $1 \%$ (Primary wound on infection were opened up and subjected to DPS or secondary closure later) and conversion was done at earliest sign of infection. Where as infection rate was $4.87 \%$ in primary closure meaning that all infected wounds were not opened up contrary to their assertion other wise conversion rate would also have been $4.87 \%$.

10. Out of 1489 wounds / casualties details are mentioned about 789 patients only (as per table 4). What happened to rest 700 ?

11. There seem to be couple of printing errors. Number of war wounds should be 1489 instead of 1481, primary closure should be 369 instead of 389 , as shown in the abstract.

12. An excellent article otherwise, few discrepancies notwithstanding.

\section{Wg Cdr PVPD Singh}

Classified Specialist (General Surgery), 7 Air Force Hospital, Kanpur208004.

Received : 14.12.2002; Accepted : 8.5.2004

trunk injuries (referring to the back alone), to highlight the non involvement of the pleural and peritoneal cavities. The comments regarding time lag since injury, in material and methods refers to the whole group of 1489 patients and not just the soft tissue group of 789 patients. The infection rate of $4.87 \%$ includes the superficial surgical site infections, which were managed by opening one odd suture and healed well. The deep surgical site infections always required conversion to secondary closure $(1 \%)$. This highlights the importance of drains, in the management of soft tissue injuries.

\section{Brig BM Nagpal vSM}

Consultant and Head, Department of Surgery, Armed Forces Medical College, Pune-411 040. 